
\title{
New Disease Reports \\ First report of Ugandan cassava brown streak virus on cassava in Democratic Republic of Congo
}

W. Mulimbi ${ }^{1}$ X. Phemba ${ }^{2}$, B. Assumani ${ }^{3}$ P. Kasereka ${ }^{4}$ S. Muyisa ${ }^{5}$ H. Ugentho ${ }^{6}$ R. Reeder ${ }^{7}$, P. Legg $^{8}$, L. Laurenson $^{9},{ }^{2}$. Weekes $^{9}$ and F.E.F Thom ${ }^{9}$

${ }^{1}$ Catholic Relief Services, Bukavu, Democratic Republic of Congo; ${ }^{2}$ Catholic Relief Services, Goma, Democratic Republic of Congo; ${ }^{3}$ Inspection Provinciale de I'Agriculture Pêche et Elevage du Sud-Kivu, Bukavu, Democratic Republic of Congo; ${ }^{4}$ Université Catholique du Graben, Butembo, Democratic Republic of Congo; ${ }^{5}$ Caritas Butembo-Beni, Butembo, Democratic Republic of Congo; ${ }^{6}$ Institut National pour l'Etude et la Recherche Agronomique, Mulungu, Democratic Republic of Congo; ${ }^{7}$ CAB International, Egham, TW20 9TY, United Kingdom; ${ }^{8}$ International Institute of Tropical Agriculture, Dar es Salaam, Tanzania; ${ }^{9}$ Food and Environment Research Agency, Sand Hutton, YO41 1LZ, United Kingdom (10) Catholic Relief Services, Nairobi, Kenya

*E-mail: julian.smith@ fera.gsi.gov.uk

Received: 26 Apr 2012. Published: 15 Sep 2012.

Ugandan cassava brown streak virus (UCBSV) and Cassava brown streak virus (CBSV) (Potyviridae: Ipomovirus) are causal agents of cassava brown streak disease (CBSD), a disease of cassava that presents a significant threat to the food security of East and Central Africa. The disease affects all parts of cassava, but notably the storage roots, making them unsuitable for consumption (Fig. 1). Although CBSD has been recognised from coastal East Africa since the 1930s (Storey, 1936), it is only in recent years that outbreaks have occurred in higher altitude areas of the Great Lakes region (Alicai et al., 2007), including parts of Uganda, western Kenya and northwestern Tanzania. In these regions, both UCBSV and CBSV (collectively referred to as CBSVs) have been reported (Mbanzibwa et al., 2011, Adam et al., 2012). More recently, the occurrence of CBSD has been confirmed in Burundi, although only UCBSV was detected (Bigirimana et al., 2011), with further unpublished records made for CBSD in Rwanda and the Democratic Republic of Congo (DRC). In DRC, visual observations of suspected CBSD symptoms have not been corroborated by laboratory tests.

In September 2011, leaf symptoms consistent with CBSD were observed during a field inspection of a cassava field [cultivar MAYOMBE (MM96/7752)] under cultivation for producing planting material in the village of Vuyinga, Lubero District, North Kivu Province, eastern DRC (N 00.07052 , E 29.04829, Altitude $1231 \mathrm{~m}$ ). For verification of the identity of the causal organism, leaf samples of affected plants were collected, dried, and sent to the Food and Environment Research Agency in the UK for analysis by real-time PCR, as described by Adams et al. (2012). It was confirmed that the leaves were positive for UCBSV and negative for CBSV (GenBank Accession No. JX291144). Additionally, positive interceptions of UCBSV were subsequently recorded during the same growing season in five out of seven multiplication fields in Lubero (highest prevalence of 18.3\%), but not in multiplication sites of other Districts. From an additional survey of over 100 farmer fields, UCBSV was identified only in two fields in Lubero and Beni Districts. These are the first confirmations of CBSD caused by UCBSV in DRC. CBSV has not been observed.

The multiplication fields within which UCBSV was confirmed were fields under the Great Lakes Cassava Initiative (GLCI, www.iGLCI.org). The field inspection and further testing of the material for CBSVs forms part of the GLCI standard practice to intercept infected materials and minimise the risk of spreading CBSVs through planting material. Under the GLCI best practice, the field material was rejected for use as planting material and designated for consumption. The original source from which the UCBSV may have originated is not known. The confirmation of the presence of CBSD in eastern DRC highlights the need to conduct a more comprehensive and wide-ranging assessment of the disease in DRC, and to apply appropriate phytosanitary measures in order to minimise the risk of further spread.

\section{Acknowledgements}

Funded through GLCI, a project co-ordinated by Catholic Relief Services and funded by the Bill and Melinda Gates Foundation.

\section{References}

Adams IP, Abidrabo P, Miano DW, Alicai T, Kinyua Z, Clarke J,

Macarthur R, Weekes R, Laurenson L, Hany U, Peters D, Potts M, Glover R, Boonham N, Smith J, 2012. High throughput real-time PCR assays for specific detection of cassava brown streak disease causal viruses, and their application to testing of planting material. Plant Pathology (early view). [http://dx.doi.org/10.1111/j.1365-3059.2012.02622.x ]

Alicai T, Omongo CA, Maruthi MN, Hillocks RJ, Baguma Y, Kawuki R, Bua A, Otim-Nape GW, Colvin J, 2007. Re-emergence of cassava brown streak disease in Uganda. Plant Disease 91, 24-29.

[http://dx.doi.org/10.1094/PD-91-0024]

Bigirimana S, Barumbanze P, Ndayihanzamaso P, Shirima R, Legg JP, 2011. First report of cassava brown streak disease and associated Ugandan cassava brown streak virus in Burundi. New Disease Reports 24, 26. [http://dx.doi.org/10.5197/j.2044-0588.2011.024.026]

Mbanzibwa DR, Tian, YP, Tugume AK, Patil BL, Yadav JS, Bagewadi B, Abarshi MM, Alicai T, Changadeya W, Mkumbira J, Muli MB, Mukasa SB, Tairo F, Baguma Y, Kyamanywa S, Kullaya A, Maruthi MN, Fauquet CM, Valkonen JPT, 2011. Evolution of cassava brown streak disease-associated viruses. Journal of General Virology 92, 974-987. [http://dx.doi.org/10.1099/vir.0.026922-0]

Storey HH, 1936. Virus diseases of East African plants. VI-A Progress report on studies of the diseases of cassava. East African Agricultural Journal 2, 34-39.

Figure 1

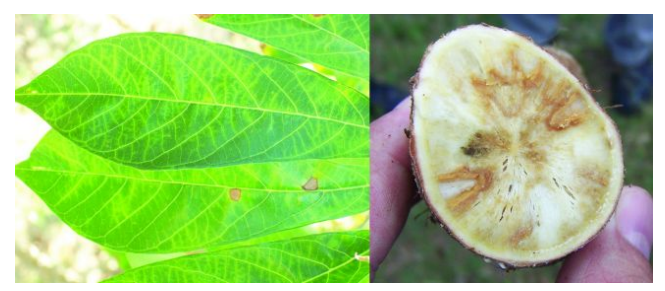

To cite this report: Mulimbi W, Phemba X, Assumani B, Kasereka P, Muyisa S, Ugentho H, Reeder R, Legg JP, Laurenson L, Weekes R, Thom FEF, 2012. First report of Ugandan cassava brown streak virus on cassava in Democratic Republic of Congo. New Disease Reports 26, 11. [http://dx.doi.org/10.5197/j.2044-0588.2012.026.011] 